\title{
GWEN ATHENE TARBOX CHILDREN'S AND YOUNG ADULT COMICS
}

London: Bloomsbury Academic, 2020 (I86 pp.)

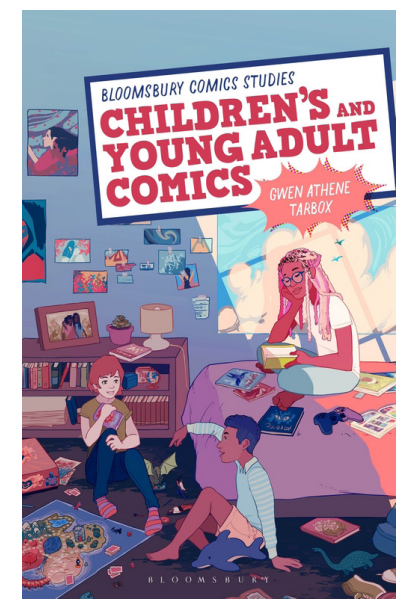

Gwen Athene Tarbox' Children's and Young Adult Comics (2020) takes as its point of departure a quote from Charles Hatfield. In his article "Comic Art, Children's Literature, and the New Comic Studies" (2006), he observed that "until recently the sustained aesthetic study of comics alongside, rather than in contra-distinction to, children's books has been neglected" (346). To a large extent, this is still the case. Tarbox sees comics and "text-based" children's and young adult literature sharing many elements, despite their mediumspecific differences, and aims to remedy the situation. Her book deals with the history, cultural aspects and critical concerns of children's comics, with special attention to the medium's relations to text-based literature and with many examples of in-depth analysis. The target audience includes students, scholars and general readers.

The book is divided into five chapters. The first one is introductory, providing the motives for writing the book, as described above, and an introduction to the subsequent chapters. Chapter 2 provides a historical overview of comics, initially focusing on fin-de-siècle comic strips and then moving through the Golden Age, the Comics Code era and onto present day. Chapter 3 deals with the social and cultural impact of children's comics and discusses the attention they are getting from various groups. The main focus of this chapter is representation. Chapter 4 examines critical use, teaching the reader about different analytical approaches with special attention to their medium-specific applications. Chapter 5 gives in-depth analytical examples of various comic works, divided into categories which are mostly genre-based. This is a lot to cover, and the publisher's para-

(C)2021 C. Mehrsteam. This is an open access article distributed under the terms of the Creative Commons CC-BY-NC 4.0 License (https:/ / creativecommons.org/licenses/by-nc/4.0/), permitting all non-commercial use, distribution, and reproduction in any medium, provided the original work is properly cited.

Citation: Barnboken - tidskrift för barnlitteraturforskning/Barnboken - Journal of Children's Literature Research, Vol. 44, 2021 http://dx.doi org/10.14811/clr.v44.571 
text labels the book a "complete critical guide to the history, form and contexts of the genre."

The structure of the book promotes the perspective that literature is shaped by broad and specific historical situations which need to be considered first, before the scholar can delve into an analysis. I will discuss chapters $2-5$ before returning to the first chapter and an assessment of the book as a whole.

Chapter 2 describes the history of children's comics from a predominantly Western perspective, grounding it in the development of picture books from the seventeenth century before starting off in earnest with 1890s comic strips. Throughout the chapter (and the book), a returning consideration is the educational uses of comics and the effects they have on young readers. In short, Tarbox traces a historical development where comics are at first considered harmful, despite having much in common with educational illustrated books, and then gradually gain the interest and recognition they receive from educators, librarians and scholars today.

The part about the Comics Code era (50s to mid-70s) is essential for the book's historical narrative. The Comics Code Authority was an industry attempt to avoid legislation through self-censorship, removing anything that at the time could be considered harmful to or have a negative impact on young readers. This is important for the comparison with text-based children's and young adult literature. Tarbox frequently comes back to the fact that she is dealing with literature written by adults for children. (While this is a common definition of children's literature, it is worth noting that a perspective admitting greater agency for children and young people, instead viewing children's literature as fiction chosen by children and young adults, would have foregrounded comics in education and research much earlier.) But as the comparison with comics from the Comics Code era makes obvious, the notion of children's literature as fiction written by adults for children entails an inherent didacticism. For a long time, text-based children's literature was ordained in schools, libraries and by well-meaning adults as a kind of antidote or protective charm against the supposedly corrupting effect of massproduced comics. This didacticism is criticized in Tarbox' book, and to some extent also theoretically problematized later in the book in relation to the work of Perry Nodelman in The Hidden Adult: Defining Children's Literature (2008). From a historical perspective, I believe that more could have been brought forth to the advantage of the following chapter, which examines comics in a contemporary context. You can also point to areas that could have been more developed giv- 
en their importance for children's comics reading, such as superhero comics and shonen and shojo manga.

Chapter 3 describes the current efforts and transformation of comics for children and young adults, dealing mainly with the lived experience of underrepresented groups. The examples, from texts such as Gene Luen Yang's American Born Chinese and Joel Christian Gill's Bass Reeves: Tales of the Talented Tenth, are interesting and may all on their own be a good reason to read this book, even for someone who isn't particularly interested in comics. I do, however, have further questions that follow from the combined issues of didacticism (in the previous chapter) and underrepresentation (in this chapter): What is the relation between æsthetics and pedagogy in children's comics? How does it work, technically, when a child is affected by a comic? Tarbox continually touches upon these questions, but it is difficult to find a definitive answer in her book. The assumption that people become what they read or are harmed by what they read (or don't read!) is very old in the domain of children's and young adult literature. You could argue that this perspective is implied both in the Comics Code and in the current transformative work on making comics more representative. As the former was normative and stifling while the latter is the opposite, this creates a theoretical tension in the book, begging to be resolved.

Chapter 4 focuses on narratology and comics theory. It brings up a great number of analytical perspectives which, again, in themselves may be reason enough to pick up this book. If you are unaccustomed to comic analysis but are trained in narratology as it is used in some other field, such as text-based literary studies or game studies, seeing it applied to comic studies and combined with medium-specific terminology for things like line, stroke, panels and speech bubbles is likely valuable. The opportunity to connect to the previous chapters is somewhat missed, however, as seen in the section on focalization. In narratology, focalization is the construction of a narrative's point of view - an interface, if you will, for the reader's connection to the fictional world. This would have been an ideal place to get down to the gritty details of reader agency and the relation between pedagogy and æsthetics in comics, tackling the above-mentioned tension through the fusion of reader response and formalist tools that is the hallmark of post-classical narratology: How are the reader's prior experiences evoked and re-organized by the comic? Is the reader subjugated to the comic's form, or is she, in fact, the one in control? How does the comic's Wirkung (that is, long term effect) happen? 
I find that Tarbox attributes quite a bit of control over the reading process to the comic artifact - the object that, at a certain point in history, has been fashioned to be interacted with in a certain way. In Tarbox' analyses, comics can have a set meaning that you either see or don't see (59), readers are forced to interact with images (96), and texts indicate how scenes should be interpreted (99). There is nothing inherently wrong with such a perspective, and Tarbox is convincing, but the perspective could also be scrutinized from a more readeroriented standpoint. The relation between images and speech bubbles likely varies a lot in individual readers' reception of a comic. If nothing else, skipping images and only reading speech bubbles is very common with beginner comic readers. In research about text-based literature reading, the role of the artifact has been played down, theoretically, since the early 70s. Yet Tarbox frequently discusses "the reader," as if it were one single unity whose reading experience is entirely dependent on, or shaped by, the comic artifact's form.

The longer analyses in Chapter 5 make use of the perspectives explained in Chapter 4, and of the historical overview and discussion on social impact in previous chapters. In this way, it is a fitting conclusion to the book. The passage on fantasy comics is a representative example. It mixes mentionings of traditional fantasy works such as L. Frank Baum's The Wonderful Wizard of Oz and J. R. R. Tolkien's The Hobbit with discussions of Jeff Smith's Bone and Eric Orchard's Bera the One-Headed Troll. The analysis of Bone is just a few paragraphs long, but Tarbox nonetheless manages to make a summary, bring in a historical reference to Hal Foster's Prince Valiant, mention how the comic was produced, relate it to traditional fantasy themes and point out how the comic's cross-over appeal is related to the stylistic juxtaposition of the protagonist's ligne claire shape and his realistically drawn object of desire. Sometimes, though, the analyses fall short of the subject they deal with. The mentioning of Art Spiegelman's Maus, for example, is expected in any book covering comics for young adults and harmonizes with the focus of previous chapters, but it is also very difficult to offer new and interesting reflections on it in such limited space. Another and less used example to bring up, given the core topics of the book, would for example have been Stan Sakai's Usagi Yojimbo, a cross-over and multi-award winning American manga about a ronin in $17^{\text {th }}$-century anthropomorphic Japan. Usagi Yojimbo is also interesting from an industry perspective, as it is one of the few longstanding comics (starting in the mid-80s and still continuing) made entirely by a single person, who also owns the brand. 
Going back to Chapter 1 and the book's motives and objectives, I consider Children's and Young Adult Comics a valuable contribution to the field. It adds to the more general discussion about children's and young adult literature, provides historical insight, promotes increased representation in comic studies and goes into analytical depth using proper tools. This is not easy to pull off, as it requires familiarity with multiple fields. Tarbox deserves a lot of credit. I do, however, feel that this is best viewed as examples of how to approach these topics rather than the "complete critical guide" to them (as advertised by Bloomsbury), in particular because of its clearly Western perspective. Manga is dealt with in several places, but I still feel that it could have contributed a lot more to the topic at hand. Perhaps you could also argue that each chapter has a different main audience, but that the book as a whole might leave each of the different reader categories with the feeling that more could have been said about their favorite part.

Christian Mehrstam

Ph.D. in Comparative Literature

University of Gothenburg 